\title{
Assimilation discourses and the production of Ella Simon's Through My Eyes
}

\author{
Jennifer Jones
}

Through My Eyes (1978) was among the first Aboriginal women's narratives available to a mainstream audience. ${ }^{1}$ Ella Simon, a prominent Biripi woman from Taree on the mid north coast of New South Wales, made oral recordings of her life story in 1973. She was determined that her resultant autobiography would prove to Aboriginal and white readers alike that 'white and black can live together; that they've got a lot in common'. ${ }^{2}$ Ella Simon believed that publishing her life story would provide a forum for her complex and then controversial views on assimilation. This article contests, on the contrary, that the editorial process that transformed Simon's oral recordings into a written text did not respect nor accurately convey Ella Simon's views on how 'white and black' could 'live together'. By examining transcripts of Simon's original oral recordings, I demonstrate how lack of cultural literacy amongst her nonAboriginal collaborators led to the prioritisation of monocultural understanding of assimilation, to the detriment of Simon's more pluralist views.

Ella Simon resolved to articulate her sense of Aboriginality and defend her positive interpretation of assimilation in response to unsettling events in the Purfleet Aboriginal community: events that reflected wider reform and change in Aboriginal affairs. Rapid changes in the governance of Aboriginal communities and in Aboriginal politics were increasingly discrediting assimilation as a concept. According to Simon, the period 1968 to 1971 severely undermined the certainties of the assimilation era at Purfleet. ${ }^{3}$ During this period two sources of paternal oversight were removed; the Station Manager in 1968, and the resident United Aboriginal Mission (UAM) missionaries in 1971. ${ }^{4}$ Purfleet matriarch Patricia Davis-Hurst observed that the loss of external supervision threatened the security of some residents:

The Welfare Board followed in the steps of the managers and was dispensed with, being replaced by the Housing Commission. ... It was

1 Following Oodgeroo's Stradbroke Dreamtime (1972) [published as Kath Walker], Margaret Tucker's If Everyone Cared (1977) and Monica Clare's Karobran (1978).

2 Simon, in Brosgarth 1977: 2.

3 Simon, extract from oral manuscript, Tape Five Side A, transcribed and edited by Jennifer Jones 2009 , transcript in the private collection of the author.

4 Purfleet had a missionary presence for the previous 71 years. See Ramsland 2001: 90-91. 
hard to comprehend that at last the reign of the manager was over. The people were confused, mainly because they always had someone telling them what to do. ${ }^{5}$

Other Purfleet residents, including a recent arrival, Aboriginal activist Kevin Gilbert, viewed the changes as inconsequential and believed that the 'new deal for black people' promised by the referendum was a sham. ${ }^{6}$ As Russell McGregor argues, disenchantment with the outcomes of the 1967 referendum influenced a new push for meaningful Aboriginal self determination in the late 1960s and early 1970s. ${ }^{7}$ Calls for Aboriginal land rights, Aboriginal distinctiveness and autonomy gained national prominence with the erection of the tent embassy at Parliament House, Canberra in January 1972. ${ }^{8}$ In February 1973, Gilbert joined other local activists in demanding self determination in Taree. These calls disturbed Ella Simon, one of Purfleet's most prominent and respectable Aboriginal matriarchs, who had long endorsed cross racial collaboration and assimilation. Advocates of assimilation often held varied opinions of the pathways and outcomes of the policy. Assimilation was not a 'monolithic strategy pursuing some predetermined ends', but a 'shifting and indeterminate discourse open to varied, even opposing inflection'. ${ }^{9}$ This article extends and complicates scholarship on the complexity of assimilationist discourses, which has focused upon national discourses, policy and policy makers. ${ }^{10}$ It argues that the editing and production of Ella Simon's life narrative reveals the diverse and competing meanings of assimilation at the grass roots level in the early 1970s. Simon's approval of assimilation was posited upon her belief in the possibility of a dynamic interaction between Aboriginal and non-Aboriginal traditions and world views - a view that would later be defined as integration. The editorial treatment of her oral manuscript starkly demonstrates how this interpretation of assimilation differed from those of her non-Aboriginal collaborators. Ella Simon advocated equal rights, respect for difference and expected that assimilation was reciprocal; that mainstream white culture would adapt to Aboriginal lifeways and accept a degree of indigenisation. Her collaborators, by contrast, acted upon the then prevalent and homogenising assumption that assimilation was a process by which Aboriginal people adjusted to western civilisation and that equal treatment was necessarily 'difference-blind'. ${ }^{11}$

5 Davis-Hurst 1996: 93.

6 Gilbert 1973: 102.

7 McGregor 2009.

8 The tent embassy, a highly symbolic public assertion of Aboriginal rights, was erected on the lawns of Parliament House by a group of Sydney based activists on Australia Day, 26 January 1972. See Goodall 1996: 338.

9 McGregor 2001: 55.

10 See for example McGregor 1999; Rowse 2005b; Haebich 2008.

11 See Taylor 1994. 


\section{The Context of Through My Eyes}

Ella Simon's commitment to Aboriginal assimilation as she interpreted it was reflected in her role as a foundation member of the Purfleet Aboriginal branch of the Country Women's Association (CWA) formed in 1961, and subsequently in the management of the Gillawarra Gift Shop (a successful Aboriginal tourism and cultural education enterprise run by a voluntary committee from 1963 to 1973). Membership in these mixed-race committees enabled Simon and her Aboriginal peers to harness the resources and power of prominent white members of the Taree community, improving outcomes in education, health, employment, and housing for the Purfleet community; outcomes that had been difficult to otherwise obtain under the rule of the Aboriginal Welfare Board (AWB) ${ }^{12}$ In February 1973, however, Black Power activists led by Aboriginal poet Kevin Gilbert ousted the mixed-race committee that operated the Gillawarra Gift Shop, insisting, "That "the people" wanted the shop'. ${ }^{13}$

By the late 1960s, the term 'black power' had come to represent a 'mood of assertiveness' that accompanied demands for recognition of Aboriginal cultural difference, rights to land and autonomous leadership of Aboriginal

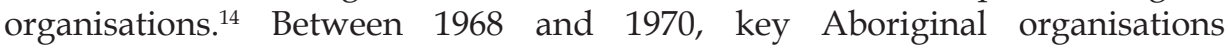
experienced increasing polarisation 'between "Establishment" and "radical" Aborigines', ${ }^{15}$ who demanded that white Australians relinquish leadership roles in Aboriginal organisations. These divisions were sometimes generational, with members of the increasingly educated and urbanised younger generation rejecting the world view of conservative Elders like Ella Simon. ${ }^{16}$ As Felton and Flanagan later explained in their Tidda's Manifesto:

If we continue to listen to white people's analysis of our oppression we will begin to question our own reality and our objectives will become oppressed. We believe that this has happened to so many of our old people who went through the missions. Our old people tend to talk of missionaries with great fondness, yet when we, as the next generation, hear about the way they were treated by Whites we react with a lot of anger. $^{17}$

Ella Simon was an 'Establishment Aborigine'; a political conservative and Evangelical (later Pentecostal) Christian with long-standing connections in

12 I examine the achievements and challenges of cross-racial collaboration in the Country Women's Association in greater depth in my forthcoming book Country Women and the Colour Bar, which is based upon research made possible by an ARC Post Doctoral Fellowship.

13 Simon 1978: 108.

14 Attwood 2003: 185.

15 Minutes, January to June 1970, Council for Aboriginal Affairs, 7 Dec 1967, Box 1, Series 1, Item 6, Barrie Dexter Papers MS4167, AIATSIS Library. The FCAATSI, Sydney based Foundation for Aboriginal Affairs, and the Victorian Aborigines Advancement League all experienced the contestation of white leadership by 'radicals' in 1969-1970. See Taffe 2005; Lothian 2005: 179-200; Broome 2010: 141

16 McGregor 2009: 348-349.

17 Felton and Flanagan 1993: 57-58 
respectable Taree circles. Her disapproval of the noisy approach of militant or even left-leaning politics was well known. ${ }^{18}$ So when Black Power advocates, under the auspices of the Purfleet Aboriginal Advancement League, threatened to damage the productive cross-racial collaborations Simon and others had carefully cultivated, she was forced to respond. The Gillawarra Giftshop Committee meeting minutes records this provocation as the exclusion of the two Taree Chamber of Commerce representatives 'who had been members of the [Gillawarra] committee since inception [and] were not invited to continue with the management' ${ }^{19}$ Ella Simon was incensed and tendered her resignation in an act of solidarity:

It was against my principles not to have a mixture of black and white. They wanted it run by Aborigines only. I just didn't want to work under an all-Aboriginal committee, that's the truth. I felt it was just another colour-bar ... Doing this wasn't assimilating them. It was just getting them back where they were, and I couldn't be any part of that. ${ }^{20}$

Simon viewed the strategies of Black Power advocates as isolationist, achieving an unwelcome return to racial segregation. Simon believed that the assertion of Aboriginality did not require a rejection of assimilation. One of the common interpretations of cultural assimilation was that Aboriginal people would willingly relinquish their Aboriginal culture and associations in exchange for civic benefits. ${ }^{21}$ Government literature suggested that Aboriginal people must 'live and work and think as white Australians do so that they can take their place in social, economic and political equality with the rest of the Australian community'. ${ }^{22}$ Ella Simon's view of assimilation varied significantly from the policy officially adopted by the New South Wales Government and from the view widely held within the mainstream white community. ${ }^{23}$ Influential anthropologist AP Elkin recognised that Ella Simon's standpoint on assimilation did not imply cultural absorption. He explained Simon's defence of assimilation in his foreword to Through My Eyes:

Mrs Simon felt that the Black Power Movement wanted to control all Aborigines as a people apart, whereas her own objective was assimilation,

18 In 1961, Ella Simon refused to assist a beloved cousin and her family when they were made homeless during the Purfleet rent strike. A political conservative, Simon was against the rent strike 'because Commo's were involved'. Faith Saunders, interview with Jennifer Jones, 19 December 2004, Taree, unpublished transcript in the private collection of Jennifer Jones. She also opposed the Freedom Ride because the activists were simply 'stirring up a hornets' nest and shooting off'. Alan Duncan quoted in Curthoys 2002: 57.

19 'New Committee for Gillawarra Shop', The Manning River Times, 2 April 1974. History of the Gillawarra Gift Shop, nd, File 3, Gillawarra Gift Shop papers, in the private collection of Alan Cowan, Forster, New South Wales.

20 Simon 1978: 108.

21 Haebich 2008: 182.

22 Department of Territories 1958. Pamphlet held in the Aboriginal branches and Associations folder, Country Women's Association of New South Wales (CWA of NSW) archives, Potts Point, Sydney.

23 See Rowse 2005a for a comprehensive discussion of the differing approaches to assimilation. 
that is, mutual respect and cooperation of Black and White in one society of Australian citizens - a goal which was later called integration. She did not mean either biological or cultural absorption. ${ }^{24}$

Ella Simon believed that assimilation could accommodate an Aboriginal sociocultural order, but she did not frame her claims with the more politically palatable term 'integration'. Here Elkin interprets Simon's standpoint on assimilation as future oriented and productive. Whilst other Aboriginal people, described by Elkin as 'disillusioned fringe dwellers' attempted to return to their 'former tribal culture' which was now in 'shreds', ${ }^{25}$ Ella Simon was weaving something new and viable:

Mrs Simon, for her part, sought neither to retreat into the traditional past, nor to reject citizenship with its responsibilities and privileges. On the contrary she sought to weave a new 'mat' of materials old and new, Black and White, and of the spiritual and moral fibres of both Aboriginal and Christian faiths. ${ }^{26}$

I presume that Elkin observed elements of this 'new mat' in his reading of Through My Eyes, a text that conforms to the Bildungsroman model of autobiography. Yet Through My Eyes, which is narrated by a single, integrated authorial persona, differs considerably from the original oral narrative in content and form. ${ }^{27}$ With recourse to the oral manuscript, this article contests that Ella Simon attempted to demonstrate the compatibility of Aboriginal and Christian world views and hence the viability of assimilation by adopting an Aboriginalised narrative form.

\section{Strands in the 'new mat'}

What historical experiences convinced Ella Simon to publicly endorse assimilation? Ella Simon was born in 1902 and raised by her maternal grandparents on Purfleet Mission which had been gazetted in response to demands by white locals for racial segregation. ${ }^{28}$ The Aboriginal reserve, originally located within the town's boundaries, had been shifted three times between 1880 and 1900 in response to white complaint; until 18 acres of land was granted as a government reserve in May 1900, two miles south of Taree on the southern side of the Manning River. ${ }^{29}$ A UAM volunteer commenced work with the Purfleet community in May 1901, the mission hall and school building

24 Elkin in Simon 1978: 7. From the 1950s some activists preferred the term 'integration' to 'assimilation' as they believed it implied a mode of incorporation into the nation that was more respectful of Aboriginality. See McGregor 2009: 345-346.

25 Elkin in Simon 1978: 9.

26 Elkin in Simon 1978: 9.

27 This article concentrates on editorial choices concerning narrative form. See Jones 2009c for examples of the impact of decisions to include or exclude particular content from Though My Eyes.

28 Byrne and Nugent 2004: 50.

29 Ramsland 2001: 75. 
was opened in June 1903..$^{30}$ One common premise amongst UAM missionaries, who were drawn from the ranks of the evangelical faithful, was the belief that conversion could be equated with the adoption of a European world view. Their fundamentalist theology was also frequently expressed in a strict and narrow set of moral principles. ${ }^{31}$ As John Harris notes, it was not until the 1960 s that cultural integration was widely accepted by many missionaries in Australia. ${ }^{32}$

The UAM became the most active of the non-denominational mission societies and as UAM missionaries worked on Aboriginal Protection Board Aboriginal Stations and Children's Homes; they became closely associated with repressive government practices. ${ }^{33}$ The influence of the UAM at Purfleet, however, declined as control of the Aborigines Protection Board increased. The Aboriginal Protection Board gained legislative power over Aboriginal people in New South Wales in 1909 and installed a live-in Manager at Purfleet in 1932. The Manager at Purfleet assumed many of the welfare and teaching roles previously occupied by the resident missionary, maintaining authoritarian control of resident's temporal needs including housing, rations and clothing. In response, the UAM moved its mission hall off the government station in 1935, in order to maintain an independent presence. ${ }^{34}$ Religious events conducted under the auspices of non-denominational groups like UAM and Christian Endeavour became one of the few avenues for cross-racial contact between Aboriginal and white women outside of paid employment.

One of the greatest obstacles to achieving assimilation was the obstruction of some in the white community who did not want to absorb Aboriginal people. This was particularly evident in rural areas of New South Wales, in which the majority of Aboriginal residents still lived. Aboriginal Stations had first been established as enclosed and supervised spaces in order to achieve segregation, creating 'a buffer against contact between Aboriginal people and whites', popularly known as the 'colour bar' ${ }^{35}$ Legislation at local, state and federal government levels limited the rights of Aboriginal people to participate in community life and to access services. These restrictions ranged from exclusion from the census, to segregated treatment in public hospitals and inferior state-delivered education. The colour bar also operated at an informal level; Aboriginal and non-Aboriginal people both had a tacit understanding of which public services or spaces were off limits to Aboriginal people. These unspoken local codes prescribed the availability of shopping facilities, saw the operation of curfews, specified tolerated locations

30 Telfer 1939: 61.

31 Harris 1990: 590.

32 Harris 1990: 551-560.

33 Harris 1990: 556.

34 Ramsland 2001.

35 Goodall 1996: 90. Enclosure also enabled the Aboriginal Welfare Board to disperse Aboriginal people who were defined as non-Aboriginal under the Aborigines Protection Act 1909 (NSW). See Read 1988: 55. Maintaining an enclosure was easier in locations where the station could be fenced and gated, or where remoteness discouraged access. As Purfleet was actually bisected by the Pacific highway, physical enclosure was impossible. Its status as an Aboriginal Station was announced by 'large and prominent notices'. Ramsland 2001: 150. 
for Aboriginal housing and determined which community organisations or social functions Aboriginal people could expect to attend; including churches, service organisations, sport and recreation venues.

Although official government policy required Aboriginal assimilation after 1951, legislated and informal rules of the colour bar meant that there was little social mixing between Aboriginal and white women. Aboriginal Stations remained off-limits to the white community, with all requests for admissions requiring the approval of the Manager. Government officials realised that assimilation could only proceed with the assistance of influential local brokers who would be willing to defy the norms of the colour bar. This was affirmed by a government publication that stated:

No matter on what scale, Government and Mission efforts cannot achieve [assimilation] - it is a matter for each individual Australian. Assimilation cannot be achieved with sporadic bursts of good will, but depends on sustained understanding and practical assistance. ${ }^{36}$

When the Country Women's Association of New South Wales began recruiting Aboriginal women into a special Aboriginal CWA branch at Toomelah Aboriginal Station near Boggabilla in 1956, Aboriginal Welfare Board authorities soon approached the organisation to provide this 'sustained understanding and practical assistance' in other locations with large Aboriginal populations around the state. ${ }^{37}$ Formed on Aboriginal Stations from 1956 to 1961, Aboriginal branches of the CWA provided a means for cross-racial mixing, skills transfer and personal development. ${ }^{38}$

Ella Simon joined the CWA in 1960 when a branch was opened on Purfleet Station. ${ }^{39}$ She soon became an active member of the CWA and other community groups including Quota and the Gillawarra Gift Shop Committee. Here Ella delivered countless lectures on Aboriginal culture to tourists and interested community groups and she would, 'really enthral them with her talks about the old days in the Aboriginal community' ${ }^{40}$ As Taree community member Pam Saunders recalled:

They were running a tourist program at Purfleet in them early days, cultural education and tourism. They would do the corroborees and tell

36 Department of Territories 1958. Pamphlet held in the Aboriginal branches and Associations folder, Country Women's Association of New South Wales (CWA of NSW) archives, Potts Point, Sydney.

37 Letter, HJ Green to Mrs AB Streeter, 29 June 1956, File C16990, Series 9, Aborigines Welfare Board Correspondence Files, State Records Authority NSW, Sydney.

38 See Jones 2009b.

39 The Purfleet CWA branch closed in 1969. Foundation member Patricia Davis Hurst attributes the decline due to 'lack of interest' and community preoccupation with new challenges of self management. Patricia Davis Hurst interview with Jennifer Jones, 8 December 2004, Taree, unpublished transcript in the collection of the author; Simon 1978: 106.

40 Alan and Judy Cowan interview with Jennifer Jones, 23 February 2010, Forster, unpublished transcript in the collection of the author. 
the stories and we'd sit around the campfire. All the tourists would come in; busloads of tourists would come in. We'd get visitors from all over the place. ${ }^{41}$

The Gillawarra Gift Shop provided a platform to assert cultural survival, challenging the common assumption that Aboriginal people of mixed racial heritage living in settled areas had 'lost their culture'. The Gillawarra Gift Shop, which had evolved into something of a community centre for Purfleet people, also provided an avenue for interaction, education and cooperation with nonIndigenous people. ${ }^{42}$ The Gillawarra Gift Shop was therefore an important forum for the assertion of Aboriginal identity and the practise of assimilation. Ella Simon's vision of a shared future was thus directly challenged when the Black Power faction of the Purfleet Aboriginal Advancement League wrested control of the gift shop committee.

\section{Narrating Through My Eyes}

Ella Simon's hurried retirement from the Gift Shop left her with time on her hands and fresh motivation to champion her beliefs. A white friend, Anne Ruprecht, who had been encouraging Ella Simon to write her life story for a number of years, suggested she use her cultural education lecture notes as a foundation for the manuscript. ${ }^{43}$ Ella Simon's strength, however, lay in oral presentation. Her cousin Faith Saunders described her as someone who was not shy to speak out, 'She was an open person, someone who talked' ${ }^{44}$ Rather than writing her autobiography, Ella Simon obtained a tape recorder and began to record in May 1973, completing the last tape in December 1973. She recorded her narrative in three distinct contexts; when she was alone, in the presence of Anne Ruprecht, and in conversation with an Aboriginal relative. As I will demonstrate below, the recording context was to have a significant bearing on the eventual narrative voice of the published text.

The immediate challenge for foundational Aboriginal women authors like Ella Simon was to communicate their story to a mainstream readership that was unfamiliar with Aboriginal experience and culture. This necessarily requires the author to adopt 'a mediating position between their own cultures and those of non-Aboriginal readers' ${ }^{45}$ The mediation process also involved another layer; the transcriber and the editor of the text, both of whom played a role in

41 Pam Saunders interview with Jennifer Jones, 19 December 2008, Taree, unpublished transcript in the private collection of the author.

42 Simon 1978: 107.

43 Their relationship was founded and consolidated through shared involvement with the Christian Endeavour Union in Taree, an evangelical youth organisation for deepening the Christian life. Anne Ruprecht interview with Jennifer Jones, 13 October 2004, Sydney, unpublished transcript in the private collection of the author. see Harris 1990 for a description of the relationship between UAM and Christian Endeavour.

44 Faith Saunders interview with Jennifer Jones.

45 Sabbioni 1996: 72. 
translating the oral narrative into written form and are predominately nonAboriginal. ${ }^{46}$ As Jennifer Martinello argues, this exchange between author, transcriber and editor involves 'display and reception, writing and reading, inscribing and interpreting' ${ }^{47}$ This brokerage role is perhaps best conducted by someone who understands and values Aboriginal cultural expression. Ella Simon's non-Aboriginal collaborators, however, were ill equipped to recognise what constituted worth in Aboriginal cultures. This failure to faithfully mediate the translation of oral narrative to written text and how this affected treatment of the theme of assimilation is the focus of the following section of the article.

Ella Simon's non-Aboriginal friend Anne Ruprecht oversaw the publishing project; applying for government funding, coordinating the transcription and publication of the manuscript. This process saw the manuscript pass through the hands of several non-Aboriginal typists, 'friends and daughters of friends' who were willing to volunteer their services or receive nominal remuneration. ${ }^{48}$ An official from the Aboriginal Arts Board of the Australia Council, a highbrow author freelancing as an editor for the Arts Board, and the publisher at Rigby were also involved in turn. ${ }^{49}$ Decisions made by these individuals crucially shaped the published text.

\section{Cultural literacy and the oral manuscript}

One of the immediate problems of interpretation faced by the collaborating transcribers and editors was the issue of audience in the manuscript. Simon recorded her oral manuscript in three distinct contexts, with each influencing her mode of address. Three of the five tapes were recorded when Simon was alone, and here she addressed her narrative to the uninformed imagined reader. ${ }^{50}$ One of the tapes was recorded in the company of Anne Ruprecht, and she is addressed as a moderately informed non-Aboriginal friend. The final tape records a yarn with her cousin Maude, whom she addressed as a highly-informed Aboriginal insider. Figure 1 below illustrates how the oral narrative addressed to the insider audience was most heavily edited; with only 15 per cent of topics covered finally included in the published text. Thirty per cent of topics narrated in the presence of Simon's non-Aboriginal friend were included in the published text, while 47 per cent of topics addressed to the imagined reader were included in the published text.

46 For a discussion of the politics of cross-racial editing see Heiss 2003; Jones 2009a.

47 Martinello 1999: 169.

48 Anne Ruprecht interview with Jennifer Jones.

49 This process is examined at length in Jones 2009c.

50 Anne Ruprecht gave me the surviving tapes, which I had digitised in 2008. I presume a number of tapes did not survive as large sections of the published text are not replicated in the oral manuscript. 


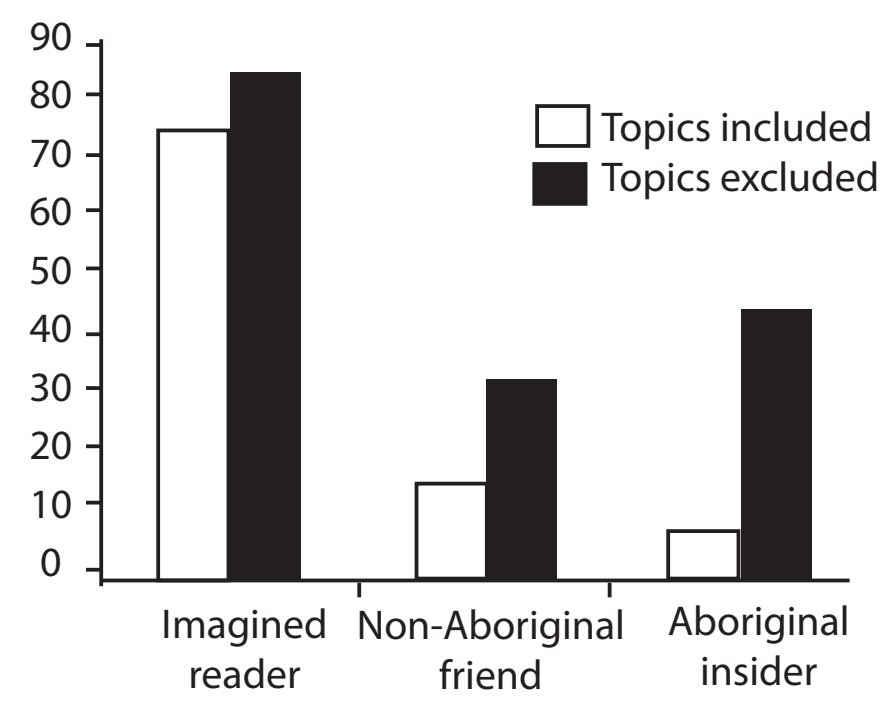

Figure 1: Editorial treatment of the three recording contexts.

Source: Compiled by author with the assistance of Edgar Burns, Sociology Department, La Trobe University.

Narrations recorded in conversation with Ella's cousin Maude adopt the conventions of 'Indigenous yarning' to regulate the recollection of family and community oral history. Yarning is a group activity that allows participants to recall the past collectively, so 'that each participant [is] able to assist and confirm the others memories'.$^{51}$ The maintenance of family and community oral history relies upon the verification of personal accounts, as the individual teller, their relations and other community members may all act as custodians for certain stories. Family and community oral history is highly esteemed and valued as intrinsically trustworthy by Aboriginal people, particularly in comparison with official records that may have proven false or defamatory ${ }^{52}$ This suspicion of the written record contrasts the general acceptance of documentary evidence among the non-Aboriginal Australian community as a source of historical knowledge that is perceived to be more reliable than remembrance. ${ }^{53}$ Clearly, the discussion format of the yarns, which concentrated upon the verification of family history topics and therefore presumed insider knowledge, proved unsuitable for adaptation into a self-focused and seamless first-person narrative expected and preferred by mainstream readers of autobiography.

Interestingly, the only yarning narratives that subsequently appeared in the published text covered topics that were also repeated elsewhere in the manuscript; that is, they were also addressed in a modified form to a nonAboriginal audience. Repetition is a characteristic of indigenous yarning

51 Barker 2008: 9.7.

52 Nugent 2003.

53 Nugent 2003. 
traditions. Walter Ong suggests that narrative originality in oral cultures relies upon 'managing a particular interaction with this audience at this time - at every telling the story has to be introduced uniquely into a unique situation' ${ }^{54}$ Ella Simon frequently repeats the same story in different recordings; each rendition had a different emphasis and often includes different details. This responds to the particular audience and the teaching intent of the narration. Eight stories are the subject of multiple telling in the oral manuscript, but these stories are featured only once in the published text. The majority of stories repeated in the manuscript are twice told; Gathering bush tucker, the story of Charlie and the goanna, Legend of the brush turkey, Legend of the kookaburra, and the story of the formidable Winmurra women. The issue of traditional marriage law and contemporary marriage practise is broached seven times, while the issue of miscegenation is addressed nine times. Repetition clearly reflects the importance of these topics to Ella Simon and their integral relationship to her narrative aims. The oral manuscripts emphasis on marriage and miscegenation clearly reflects her interest in assimilation and its outcomes. In both of these cases the multiple narrations are consolidated by the editors and represented only once in the published text.

The following section of this article examines the repetition of two linked stories, an account of family tragedy during the 1912 floods and the legend of Coolumbra, which are accorded three recitations in total. Each recitation addresses a distinct audience; the uninformed imagined reader, the moderately informed non-Aboriginal friend and the Aboriginal insider. Each version is told with a distinct purpose and with deliberate inclusions or exclusions that relate to the audience and intention of the retelling.

\section{The 1912 floods and the legend of Coolumbra}

The first rendition, on Tape Three Side A, was recorded in the absence of a physical audience, and hence addresses the imagined reader. It is a story that recalls the wisdom of a revered elder, Granny Russell, and her use of the oral tradition to comfort her grieving family after the 1912 flood. The narrative intention of the story is also to assert the compatibility of Aboriginal and Christian religions.

Tape Three Side A [addressing imagined audience]

The six years of my schooling was the most miserable time of my life, ... nobody understood me. We had a good life at home; we read the Bible each night. It was here that we heard all about the legends and the Dreamtime of the Aboriginals. An awful time came; it rained for six weeks and the floods came. Each week the river would rise and we felt that the worst had come. Grandfather was very ill, and he died. Then the Uncle died; within a few day of one another, then the Aunt, three weeks later, all because they couldn't get the Doctor's attention, because of the

54 Ong 1982: 41. 
floodwaters. Four children [were] left by my Aunt, and a wife and two children left by the Uncle. Grandma ... tried so hard to keep the family. She had five of us, four of her own and myself. The Uncle was the eldest; he was 16 years of age. He started to work in the bush cutting sleepers [Tells story of hardship keeping family]. It was in this period of time, at night, that Ma told us the legend of Coolumbra, a type of Jesus. [Retells legend]. This is like the story in the Bible often we would read at night, and grandmother would line it up with the story of Coolumbra, about Jesus feeding his disciples on fish and honey. This man was speared by a hostile tribe, the legend goes, and he was tied to a tree. His mother knew this, as the blood dripped from the bulli baun. This is only a legend, but how true. ${ }^{55}$

In the context of unhappiness at school and the tragic death of three family members, including an Aunty that Ella loved as a mother and Grandfather she considered to be her 'daddy', Granny Russell recalls a legend that affirms the compatibility of the 'two worlds' the family straddles; Aboriginal and Christian. The juxtaposition of the family tragedy and the Coolumbra story thus links a specific event in family and community experience to broader processes of colonialism and cultural survival, offering 'options available for determining the meanings of events'. ${ }^{56}$ Granny Russell uses her story to authoritatively demonstrate the viability of religious syncretism, to offer comfort and to empower her mourning family. In this regard, Granny Russell's Aboriginal oral history is future oriented. As Deborah Bird Rose explains, 'oral narratives show how to reclaim the past in order to liberate the future' ${ }^{57}$ That is, the stories anchored in the past also address the needs of the present. They offer the young Ella, and ultimately the imagined readers of her life story, a cultural bridge to make sense of lived experience in a post-colonising society. This is particularly significant given the prevailing view amongst UAM missionaries, the missionary group that served at Purfleet, that Aboriginal people must relinquish their cultural beliefs in order to prove their conversion and assimilation. Granny Russell and Ella Simon refute this belief.

55 Simon, extract from oral manuscript, Tape Three Side A. This extract, originally 640 words, has been edited to 450 words for brevity. The Coolumbra legend is as follows, 'She told us how he came across from the Wallamba River to Red Head. Saying goodbye to his mother, he told her to hang up his bulli baun, which meant his loincloth, and if she saw blood dripping from it, she would know that he had been killed. Now Coolumbra was a good man. He was very clever and the people were very jealous of him. One day, they planned that they would kill him, because he was too good for them. They started to travel, and as they got near Blackhead, in the Manning district, he came across a cave. Here you are not able to go across, you have to go around. The people had to leave Coolumbra then, because he was able to walk across the opening without any trouble. The legend goes that it took three days for them to walk around. When the people arrived after the three day walk around the beach, they arrived at the beach were Coolumbra was; he had a fire burning with fish cooked on the coals. He also had honey for them to eat'.

56 Bird Rose 1989: 138.

57 Bird Rose 1989: 146. 
Simon also mobilises the authority of her grandmother at another point in the oral narrative in order to demonstrate religious syncretism and the validity of Aboriginal cultural practise. In a discussion of initiation ceremonies, which was not included the published text, she narrates:

The initiation ceremony was very lovely. The grandmother had been to a few of them, and she said that some of it was very pathetic; the son would be taken out and they was given that law [describes circumcision]. They had a purification, and that's biblical you know, they drug you through the fire to be purified. They drug you over the fire, and to me, years after I become interested in the bible and read so much of the Bible, I could see lots of things in the initiation. It was really parts of the Bible story. ${ }^{58}$

Here Simon's parallel between Aboriginal initiation practices and Christian purification is validated by the grandmother's eyewitness account. This appeal to an esteemed elder demonstrates that her interpretation has the highest possible credentials and offers an opportunity for the non-Aboriginal collaborators to show respect for an Aboriginal world view. Nevertheless, the topic was not included in the published text.

The second rendition of the 1912 flood, recorded on Tape Four Side A, recounts the family tragedy narrative in greater depth and excludes the link with the Coolumbra legend. As the yarning narrative addresses an insider audience of Aboriginal family and community members, its primary purpose is not to recount familiar legends, but to confirm and perpetuate family history. Roberta Sykes argues that a primary function of the representation of Aboriginal characters in Aboriginal literature is to locate and validate 'black heroes for our children'.$^{59}$ In this narrative, the heroic actions of Maude's father, who swims the swollen Manning River, and the resilience of Granny Russell, are the primary focus.

Tape Four Side A [addressing Aboriginal audience]

Ella: Do you remember your mother when she died?

Maude: I can just remember them; we stood around the door lookin' in, you know. Dad was there cryin'.

Ella: Grandmother was nursing and we used to take it in turns, you know, to sit up with her. It was raining - oh it rained for weeks and weeks and weeks. Grandfather and Uncle Victor was buried just before your mother, about six weeks before your mother died. Your mother got pneumonia after all this weather. Auntie Mabel got pleurisy, and Aunty Elsie had bronchitis; there was a whole sick crew. ... I remember your mother tossing and turning, you know, and your father tried to get to town. He couldn't get the doctor out because that was a terrific flood and that would be

58 Simon, extract from oral manuscript, Tape Five Side B. This extract, originally 180 words, has been edited here for brevity.

59 Roberta Sykes quoted in Martinello 1999: 169. 
about 1912 ... Your father swam; he put his clothes on top of his head to go to get your mother's medicine from the doctor. [Describes at length the courageous attempt by Maude's father to get medicine] But they couldn't save her life. She died, and I felt that the bottom had fallen out of my boat too when she died, because I loved her so very much. Well I thought that was a terrible trial for our Granny Russell, ... She must have been a wonderful woman...

Maude: Yeah

Ella: To put up with all that and go through it. ${ }^{60}$

In contrast to the first telling of the 1912 flood narrative, which is intended for a non-Aboriginal audience, this version addresses Aboriginal listeners. Emphasis is placed upon the identity and experience of a range of characters; the audience hears about Granny Russell, Grandfather Russell, Maude's Mum and Dad, as well as Victor, Elsie, and Mabel, 'the whole sick crew'. Aboriginal family history is characteristically 'crowded with the names of family members', as naming honours their experience and makes their memory available to present and unborn generations. ${ }^{61}$ Ella Simon apparently appreciated that non-Aboriginal audiences would not be interested in the personalised version of this story, so she depopulates and generalises it for a wider readership in the rendition on Tape Three.

The third narration, on Tape Five Side A, was recorded in the presence of Ella Simon's non-Aboriginal friend Anne Ruprecht. This telling of the Coolumbra legend, like the description of the initiation ceremony discussed previously, is contextualised by a shared belief in Christianity. Although the 1912 flood narrative is excluded, the coda to this version of the Coolumbra legend is linked to the flood experience. In this version Ella contests that rain events result from the failure of strangers to observe Aboriginal protocols. This rendition of the Coolumbra legend not only illustrates links between Aboriginal spirituality and Christianity, but also the need for non-Aboriginal Australians to respect an Aboriginal world view.

Tape Five Side A [addressing non-Aboriginal friend]

I don't know if I told you the story of Coolumbra? Coolumbra means 'Jesus' and he was a very, very clever man. Now my Grandmother told me this when I was a little girl, because she was very religious. She told me the story of Coolumbra. She said he was very clever and he was so clever that everybody was jealous. Then one day, they said they was going to kill him. This happened somewhere along the Tuncurry water, on that side. ... He told his mother that when he left there, they wear a thing around their waist called a bulli baun, which is to put in their

60 Simon, extract from oral manuscript Tape Four Side A. This extract, originally 716 words, has been condensed for brevity.

61 Dianne Barwick quoted in Nugent 2003: 150. 
spears or their boomerangs. It's made out of kangaroo strips or human hair. Well, this bulli baun was to be hung up in the mother's camp. He said to the mother; ' when I go and you see blood dripping off it, you will know that they have killed me', so he left to go. When he got along the road, he got with some people that was going down the coast. He told them that there was a gorge that you couldn't go across - they had to go around. According to the legend, it was three days that they walked around. But he told them that he would go across and meet them on the other side. When they got to the beach side, he was there sitting with the fire made and fish cooked on the coals, and some honey for them to eat. Now that is a bible story; about the honey and also about the fish cooking on the coals because Peter found that when he came ashore - the fish was cooked on the coals. So, it is the same story. Then when he got over to Redhead, that's just how it is; he was killed. He was speared and hung on the tree. That tree was there when I was a girl. They used to tell me when I went down there that we weren't to touch a certain tree or take a leaf off it, because we would make it rain. This was a legend - a story tree - and we weren't to touch it. We were afraid to touch it. Now, if you was a stranger, and you walked over to the sea, you would have to sing out in the language, 'it's only me' then you would be able to swim, and there would be no rain or anything to disturb or wind or anything to bother you; you would tell them that you were coming. ${ }^{62}$

As with the first telling, this recitation links past, present and future to Aboriginal place and culture. By aligning the Coolumbra story with Christian Gospel stories, Ella Simon establishes the contemporary relevance of Aboriginal spiritual beliefs for Aboriginal people living in settled areas. ${ }^{63}$ She also indicates the level of respect that should be ascribed to these beliefs. Further, Simon mentions the location and survival of the 'story tree' and describes how 'you', the 'stranger' should make an approach. This mode of address invites all strangers who inhabit Aboriginal places, including contemporary readers, to understand and respect Aboriginal temporality.

The complex intersection of audience, form and narrative intention in these three versions of the Coolumbra story and the family tragedy of 1912 are not reflected in the single version published in Through My Eyes. The editors chose to combine versions one and three, and to delete the content of version two, which directly addresses the interests of Aboriginal readers.

Published text: Chapter two, page 31

All my life I have felt that everybody misunderstood me, especially when I was little ... The only really happy times, when I felt I belonged was when we got together at night and grandmother would make us read

62 Simon, extract from oral manuscript Tape Five Side A.

63 For example, the three day quest, the crucifixion, fishes and loaves and honey all hold biblical resonance. 
the bible. ... Then she would bring us right back to the old Aboriginal way of thinking and talking about the legends ... I was so happy sitting there and listening to the beautiful stories she told us and they were so near to the bible stories we had just read. Then she would tell us about Coolumbra. Coolumbra was travelling with his tribe from the Wallamba to the coast near Blackhead. He said 'goodbye' to his mother and told her to hang up his 'bulli baun' (loin cloth made from kangaroo skin) and when she would see blood dripping from it, she would know he had been killed. Now, Coolumbra was a very good man and so clever that others were jealous and said they would kill him. When they got to an opening in the rocks along the seashore, they could not cross it so he told them to go around. He crossed the opening, and when the others arrived, there was Coolumbra on the beach with a fire burning and fish cooking on the coals and he also had honey for them to eat. His enemies were able to catch him there, tie him to a tree and they then speared him to death. His mother knew he was dead because blood dripped from his bulli baun as he had said. I was taken to the only tree on that beach, a mangrove tree. We were told not to touch this tree. If we did, it would bring very heavy rain. ${ }^{64}$

By excluding reference to the 1912 flood, the published version fails to indicate the strategic significance of Granny Russell's retelling of the Coolumbra story within the context of Aboriginal historical experience. Rather than asserting the contemporary relevance of the Coolumbra story, Granny's tale is framed as 'the old Aboriginal way of thinking and talking', relegating it to the bygone past. The published version also removes Ella Simon's direct address to 'you', the 'stranger'; whose failure to show respect to country is implicated as causing heavy rain and destructive winds. Instead, in the actions of the Aboriginal participants in the story, 'we ... would bring very heavy rain' by touching the story-tree. These editorial decisions silence testimony to Aboriginal resilience and survival and deny ontological coevality between Aboriginal and Western cultures. ${ }^{65}$

This examination of Ella Simon's oral recordings clearly demonstrates that the Aboriginalisation of narratives published in the 1970s depended upon the cultural literacy of the collaborating parties; namely the transcriber and editor and publisher. As Joseph Pugliese reminds us, 'the meaning of a text is ... critically dependent upon the specific cultural literacies they bring to any reading of a text' ${ }^{6}{ }^{66}$ Ella Simon's collaborators lacked the cultural literacy required to value important cultural characteristics of her oral narrations. Charles Taylor argues that non recognition or misrecognition 'can be a form of oppression, imprisoning someone in a false, distorted and reduced mode of being' ${ }^{67}$ Ella Simon recorded her life story in response to provocation by Aboriginal activists who were intent

64 Simon 1978: 31.

65 See Fabian 1983.

66 Pugliese 2001: 98.

67 Taylor 1994: 25. 
on self determination and dismissive of assimilation, a doctrine and mode of living that she held in high esteem. By textualising features of her oral tradition and demonstrating the validity of religious syncretism, Ella Simon attempted to prove to Aboriginal and white audiences that assimilation did not require the rejection of Aboriginality. She sought to demonstrate that assimilation, or 'white and black liv[ing] together', could include both the equalisation of rights and entitlements, and respect for cultural difference. She envisaged her life story as a means to develop respect for Aboriginal culture amongst the non-Aboriginal community. Ella Simon also recounted different versions of particular stories in order to provide a resource that met the needs of an Aboriginal audience. The failure of her collaborators to acknowledge the value of the oral features of her narration suggests the assumption of a less hospitable view of assimilation; that being treated equally required the homogenisation of difference. Such assumptions hampered the capacity of the published life story to fulfil important aims and ultimately led to the cultural impoverishment a foundational Aboriginal life narrative.

\section{References}

\section{Archival sources}

History of the Gillawarra Gift Shop, nd, File 3, Gillawarra Gift Shop papers, in the private collection of Alan Cowan, Forster, New South Wales.

Letter, HJ Green to Mrs AB Streeter, 29 June 1956, File C16990, Series 9, Aborigines Welfare Board Correspondence Files, State Records Authority New South Wales, Sydney.

Minutes, January to June 1970, Council for Aboriginal Affairs, 7 Dec 1967, Box 1, Series 1, Item 6, Barrie Dexter Papers, MS4167, Australian Institute of Aboriginal and Torres Strait Islanders Studies Library, Canberra.

Simon, Ella May-December 1973, oral manuscript, five tapes, transcribed and edited by Jennifer Jones 2009, transcript in the private collection of the author.

\section{Newspaper}

\section{The Manning River Times}

Commonwealth Government, Department of Territories 1958, 'Assimilation of Our Aborigines', Government Printer, Canberra. Pamphlet held in the Aboriginal branches and Associations folder, Country Women's Association of New South Wales archives, Potts Point, Sydney. 
ABORIGINAL HISTORY 2012 VOL 36

\section{Published sources}

Attwood, Bain 2003, Rights for Aborigines, Allen \& Unwin, Crows Nest, New South Wales.

Barker, Lorina 2008, '“Hangin' out" and "Yarnin": reflecting on the experience of collecting oral histories', History Australia 5(1): 9.1-9.9.

Bird Rose, Deborah 1989, 'Remembrance', Aboriginal History 13(2): 135-148.

Broome, Richard 2010, 'At the grass roots of white support: Victorian Aboriginal Advancement League branches 1957-1972', The La Trobe Journal 85, May: 141.

Byrne, R Denis and Maria Nugent 2004, Mapping Attachment: a Spatial Approach to Aboriginal Post-contact Heritage, Department of Environment and Conservation, Hurstville, New South Wales.

Clare, Monica 1978, Karobran: The story of an Aboriginal girl, Alternative Publishing Co-operative Limited, Sydney.

Curthoys, Ann 2002, Freedom Ride. Allen \& Unwin, Crows Nest, New South Wales.

Davis-Hurst, Patricia 1996, Sunrise Station, SunBird Publications, Taree.

Fabian, Johannes, 1983, Time and the Other: How Anthropology Makes Its Object, Colombia University Press, New York.

Felton, Catrina, and Liz Flanagan, 1993, 'Institutionalised feminism: a Tidda's perspective', Lilith: A Feminist History Journal 8, Summer: 53-59.

Gilbert, Kevin, 1973, Because a White Man'll Never Do It, Angus \& Robertson, Sydney.

Goodall, Heather 1996, Invasion to Embassy, Allen \& Unwin, Crows Nest, New South Wales.

Haebich, Anna 2008, Spinning the Dream: Assimilation in Australia 1950-1950, Fremantle Arts Centre Press, Fremantle.

Harris, John 1990, One Blood: 200 Years of Aboriginal Encounter with Christianity: A Story of Hope, Albatross Books, Sutherland, New South Wales.

Heiss, Anita 2003, Dhuuluu-Yala = to Talk Straight: Publishing Indigenous Literature, Aboriginal Studies Press, Canberra. 
Jones, Jennifer 2009a, Black Writers White Editors: Episodes of Collaboration and Compromise in Australian Publishing History, Australian Scholarly Publishing, Melbourne.

- 2009b, 'More than tea and scones: cross-racial collaboration in the Country Women's Association of New South Wales and the ethos of countrymindedness', History Australia 6(2): 41.1-41.9.

- 2009c, 'Perpetuating white Australia: Aboriginal self-representation, white editing and preferred stereotypes', in Creating White Australia, Jane Carey and Claire McLinsky (eds), Sydney University Press, Sydney: 156-172.

Lothian, Kathy 2005, 'Seizing the time: Australian Aborigines and the influence of the Black Panther Party', Journal of Black Studies 35(4): 179-200.

Martinello, Jennifer 1999, 'Text and transposition: Aboriginality, representation and reappropriation', in Indigeneity: Construction and Re/Presentation, James N Brown and Patricia M Sant (eds), Nova Science Publishers Inc, New York: 159-175.

McGregor, Russell 1999, 'Wards, words and citizens: A.P. Elkin and Paul Hasluck on assimilation', Oceania 69(4): 243-259.

- 2001, 'From Old Testament to New: A. P. Elkin on Christian conversion and cultural assimilation', Journal of Religious History 25(1): 39-55.

- 2009, 'Aboriginal activism in the late 1960s and early 1970s', Australian Historical Studies 40(3): 343-360.

Nugent, Maria 2003, 'Aboriginal family history: some reflections', Australian Cultural History 23: 143-154.

Ong, J Walter 1982, Orality and Literacy: The Technologizing of the Word, Routledge, London.

Pugliese, Joseph 2001, “"Fighting with our tongues": the politics of genre in Aboriginal oral histories', Oral History Review 28(2): 85-99.

Ramsland, John 2001, Custodians of the Soil: A History of Aboriginal-European Relationships in the Manning Valley of New South Wales, Greater Taree City Council, Taree.

Read, Peter 1988, A Hundred Years War: The Wiradjuri People and the State, Australian National University Press, Rushcutters Bay, New South Wales.

Rowse, Tim 2005a, 'The certainties of assimilation', in Contesting Assimilation, Tim Rowse (ed), API Network, Perth: 237-249. 
- 2005b, 'Introduction', in Contesting Assimilation, Tim Rowse (ed), API Network, Perth: 1-26.

Sabbioni, Jennifer 1996, 'Aboriginal women's narratives: reconstructing identities', Australian Historical Studies 27(106): 72-78.

Simon, Ella 1978, Through My Eyes, Rigby, Adelaide.

Taffe, Sue 2005, Black and White Together: FCAATSI: The Federal Council for the Advancement of Aborigines and Torres Strait Islanders 1958-1973, University of Queensland Press, St Lucia, Queensland.

Taylor, Charles 1994, 'The politics of recognition', in Multiculturalism: Examining the Politics of Recognition, Amy Gutmann (ed), Princeton University Press, Princeton: 25-73.

Telfer, EJ 1939, Amongst Australian Aborigines: Forty Years of Missionary Work. The Story of the United Aborigines' Mission, Fraser \& Morphett, Winsor, Victoria.

Tucker, Margaret 1977, If Everyone Cared, Ure Smith, Sydney.

Walker, Kath 1972, Stradbroke Dreamtime, Angus \& Robertson, Sydney. 